\title{
Assessment of the microbiological quality of rain water: A case study of selected water scarce area in Bangladesh
}

\author{
Minhaj Uddin Ahmed, Ahmad Kamruzzaman Majumder*, Md. Sahadat Hossain and Abdullah Al Nayeem \\ Department of Environmental Science, Stamford University Bangladesh, 744, Satmasjid Road, Dhaka 1209, \\ Bangladesh
}

Received 03 June 2018/Accepted 12 July 2018

\begin{abstract}
Availability as well as access to drinking water is one of the considerable constraints for achieving sustainable goals in many countries while microbial contamination has exacerbated this issue more significantly. The increasing trend of population and industrialization for economic growth has adversely been affecting fresh water resources that eventually leading to scarcity of available drinking water. Hence, controlling water pollution along with focusing on alternative water sources are important for ensuring access to safe drinking water. This study aimed to determine the biological water quality parameters of rainfall water in the water-scarce areas of Bangladesh. About sixty rainwater samples collected from seven different districts were collected for microbial analysis in particular Total Coliform (TC) and Fecal Coliform (FC) by using membrane filtration and direct counting method. The result found that $70 \%$ of samples were free from total coliform, whereas only $5 \%$ samples showed above 100 colonies. On the other hand, $83 \%$ samples were free from fecal coliform, whereas only $2 \%$ samples were within the range of 11-100 colonies. This study has also revealed that most of the samples collected from Rangamati and Khulna district were free from total coliform and fecal coliform. This study may also encourage people living in these water scarce areas to come forward for rainwater harvesting system as a prospective tool for achieving sustainable goal in drinking sector of Bangladesh.
\end{abstract}

Key words: Water-scarce; Drinking Water; Total Coliform; Fecal Coliform

Safe water supply is most important factor which plays a drastic role to protect human health in a society $(1,2)$. Disease producing pathogens like- viruses, bacteria, protozoa, worms etc. should be absent in water which can be used for drinking and cooking purpose (3). Total coliform and fecal coliform is originated from fecal contamination, which contribute to cause water borne disease in human.

Bangladesh is one of the most densely populated country in the world. The increasing rate of population is much higher than food, water, space of living etc. South-eastern part of Bangladesh is hilly region (Ranghmati, Bandarban and Khagracari districts) and south-western part is mostly coastal region (Khulna, Satkhira, Barishal, Bagerhat, Patuakhli). Availability of safe drinking water is one of the most important challenges for these regions. Most of the people in hilly areas rely on the stream, lake and river for drinking water. Meanwhile welling up ground water in hilly areas are very difficult while coastal people suffer by drinking water with high salinity. Consequently, some of areas of south-western part are more vulnerable to drinking water. Due to tide, inland water often contaminated with sea water that increase salinity and push people to collect drinking water from far away.

*Corresponding Author: Mailing address. Professor Dr. Ahmad Kamruzzaman Majumder, Department of Environmental Science, Stamford University Bangladesh, 744, Satmasjid Road, Dhaka 1209, Bangladesh, Bangladesh; Email: kamrul_sub@hotmail.com.
Bangladesh has almost 230 rivers which supply huge amount of water every year. Different City Corporation in Bangladesh supply river water for drinking purpose to the city. However, most of the cities are now dependent on the quality of ground water. According to Rahman et al. 2014 (4), currently 80-90\% of drinking water in Dhaka city provides from ground water for surrounding river water pollution. Moreover, contamination with total coliform and fecal coliform also indicate the serious water pollution.

Fecal coliform are considered to be present in the intestine of warm-blooded animals. Presence of fecal coliform can be considered as an indication of animal or human waste.

The average rainfall in Bangladesh is $2400 \mathrm{~mm}$ and $70 \%-80 \%$ occurs during the rainy season (June-October) Where $80 \%$ occurs in the southwestern part of the country. Therefore, rainwater harvesting system can be used for household works. Considering this prospect as well increasing local people acceptance, it has become important to determine the quality of rainwater in these areas. In this vein, this study aimed to analyze the microbial quality of rain water for ensuring the safe drinking water for the people living in the water scarce areas of Bangladesh.

\section{MATERIALS AND METHODS}

Study area. A total of 60 water samples were collected from the Rainwater Harvesting System of Rangamati, Khagrachhari, Bandarban Manikganj, Khulna, 
Satkhira and Bagherhat districts (Figure 1) for testing of biological parameter. 10 individual samples from each district were collected whereas 5 samples for Satkhira and Bagerhat.The general quality of rainwater determined in the water quality laboratory of NGO Forum for Public Health.

Membrane filter method. The membrane filtration method gives a direct count of total coliform and fecal coliform present in a given sample of water. A measured volume of water is filtered, under vacuum, through a cellulose acetate membrane of uniform pore diameter, usually $0.45 \mu \mathrm{m}$. Bacteria are retained on the surface of the membrane which was placed on a suitable selective medium MacConkey agar plate and incubated at an appropriate temperature i.e., $44.5{ }^{\circ} \mathrm{C}$ for fecal coliform and $37^{\circ} \mathrm{C}$ for total coliform. If coliform and/or fecal coliform are present in the water sample, characteristic colonies form that can be counted directly (5-7). However, this technique is not suitable for natural waters containing very high levels of suspended material, sludge's and sediments particularly all of which could block the filter before an adequate volume of water has passed through (8-9).

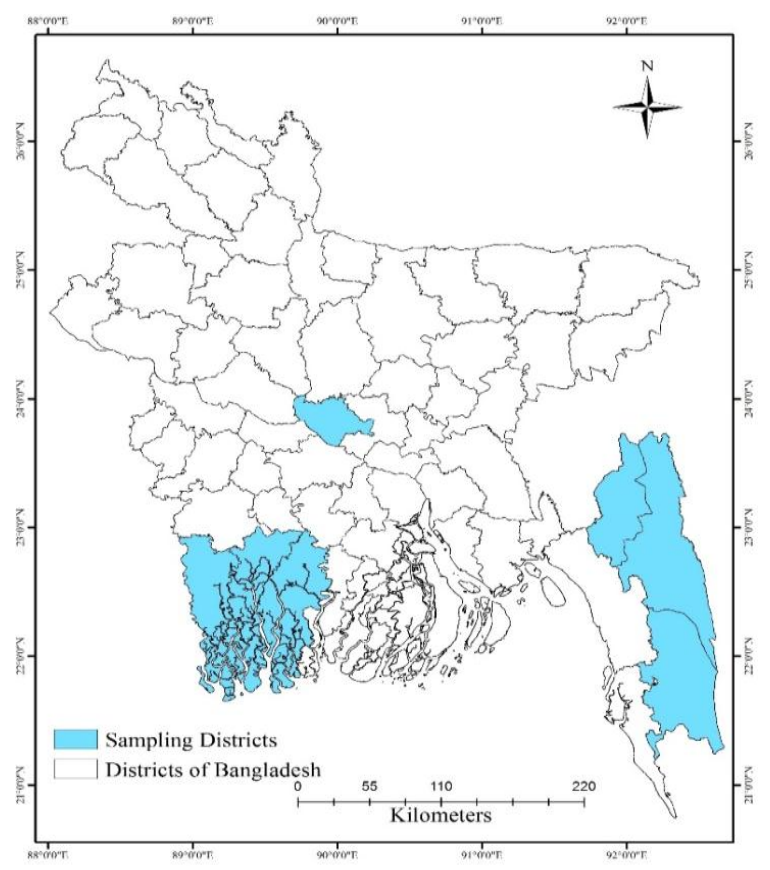

FIG. 1. Study Area Map

\section{RESULTS AND DISCUSSION}

A total of 60 water samples were collected from the Rainwater Harvesting System of Manikganj, Khulna, Rangamati, Khagrachhari, Bandarban, Satkhira and Bagerhat districts which was constructed by direct supervision of NGO Forum for Public Health at different period for testing of microbial parameters. The detailed findings were discussed below:

Microbial Parameters. The result revealed that $70 \%$ of samples are free from total coliform, $13 \%$ was within the range of $1-10,12 \%$ within the of $11-100$ and $5 \%$ is above 100 colonies respectively. On other hand, 83\% was free from fecal coliform, $15 \%$ was within the range of $1-10$ and $2 \%$ was within the range of $11-100$ colonies (Table 1). This study found that most of the samples were free from microbial contamination or were within the range of Bangladesh Environment Conservation Rules (10). About 42 (70\%) samples out of 60 were found to be free from total coliform, whereas $18(30 \%)$ samples were contaminated with different number of colonies. Besides, there were $50(80 \%)$ samples were found to be free from fecal coliform, whereas only 10 (20\%) samples were found to be contaminated with them.

The gradual anthropogenic and natural pressure on water resources are leading to the scarcity of safe drinking water. Consequently, demand for alternative sources for safe drinking water has been considered as the centric issue for sustainable development of a community and/or a country. For rainwater harvesting system, it is important to know the quality of the rainwater especially bacteriological data and information for making decisions on whether the water is safe or unsafe for human drinking purposes. This study showed a prospect to utilize rainwater in Bangladesh due to considerable amount of rainfall and free from microbes. Therefore, this system may be introduced in not only water scarce but also salinity prone areas for ensuring safe drinking water to all people. The major risk associated with rainwater harvesting comes from fecal matter that may get washed into the tank (one particular risk is associated with Salmonella from bird faces). Sometimes, the rooftop is coated with lead, zinc, nickel, different types of color etc. which has potential for metal contamination of the rain water harvested water. In that case, it is recommended to use the corrugated iron sheet as a roof top without any coating. Sometimes, in rural areas, rooftop is made of straw and different types of leafs those usually can contaminate rainwater. Therefore, basic system and collection information can be provided to the community people to get rid of microbial and other contamination. Meanwhile, rooftop harvesting system in urban areas may contribute to reduce human footprint on ground water .Hence, government can provide basic information and financial assistance to set up rainwater harvesting system in household level.

\section{CONCLUSION}

Being a overcrowded country, the surface water are contaminated with different types of pathogenic microorganisms which can cause serious enteric diseases after drinking. Collecting ground water is a good method to fill the drinking water requirements in plain areas. But in costal reasons there is scarcity of drinkable water due to high salinity and in hilly areas it is quite impossible to collect ground water. So in these areas, harvesting the rain water is a good alternative which can meet the demands for drinking water with simpler harvesting techniques. If it can be maintained from being contaminated with metals from or near the harvesting area as well as from animal and bird fecal matters, rainwater collection for drinking purpose will be much safer and easier method. 
TABLE 1. Districts wise coliform test results

\begin{tabular}{|c|c|c|c|c|c|c|c|}
\hline \multirow{4}{*}{ District } & \multirow{4}{*}{$\begin{array}{c}\text { No. of } \\
\text { Sample } \\
\text { Tested }\end{array}$} & \multicolumn{6}{|c|}{ Water Quality test information } \\
\hline & & \multicolumn{3}{|c|}{ TC (0/100 mm lit $)$} & \multicolumn{3}{|c|}{ FC (0/100 mm lit) } \\
\hline & & \multicolumn{2}{|c|}{ Result } & \multirow{2}{*}{$\begin{array}{c}\text { Bangladeshi } \\
\text { Standard (ECR- } \\
\text { 1997) }\end{array}$} & \multicolumn{2}{|c|}{ Result } & \multirow{2}{*}{$\begin{array}{c}\text { Bangladeshi } \\
\text { Standard (ECR- } \\
\text { 1997) }\end{array}$} \\
\hline & & $\mathbf{0}$ & $>0$ & & $\mathbf{0}$ & $>0$ & \\
\hline Manikganj & 10 & 6 & 4 & 0 & 8 & 2 & 0 \\
\hline Khulna & 10 & 8 & 2 & 0 & 9 & 1 & 0 \\
\hline Rangamati & 10 & 8 & 2 & 0 & 9 & 1 & 0 \\
\hline Khagrachhari & 10 & 7 & 3 & 0 & 8 & 2 & 0 \\
\hline Bandarban & 10 & 6 & 4 & 0 & 7 & 3 & 0 \\
\hline Satkhira & 5 & 3 & 2 & 0 & 5 & 0 & 0 \\
\hline Bagerhat & 5 & 4 & 1 & 0 & 4 & 1 & 0 \\
\hline Total & 60 & 42 & 18 & & 50 & 10 & \\
\hline
\end{tabular}

\section{CONFLICT OF INTEREST}

Authors have no conflict of interest.

\section{ACKNOWLEDGEMENT}

NGO Forum for Public Health for providing their Water Quality Laboratory and financial support by NGO \& Civil Society Networking Project, DANIDA and CMWSSPCHT project, European Commission.

\section{REFERENCES}

1. Ofosu HA, Yaa A, Selormey VY, Musah A, Antwi P. 2014. Microbial quality of household drinking water in the sunyani municipality of Ghana. J. Environ. Earth Sci.. 4 (6): 72-77.

2. WHO (World Health Organization). 2008. Guidelines for Drinking-water Quality, Incorporating $1 \mathrm{st}$ and 2nd Addenda, Volume 1, Recommendations. $3^{\text {rd }}$ ed. WHO, Geneva, Switzerland.
3. Adam BAA, Hassan BM, Adam D, Hussein AM. 2016. Assessment of microbial quality of drinking water in Rabak Town, White Nile State , Sudan 2010. Intl. J. Technol. Enhan. Emerg. Eng. Res. 4 (2): 6-8.

4. Rahman S, Khan MTR, Akib S, Che N, Biswas SK, Shirazi SM. 2014. Sustainability of rain water harvesting system in terms of water quality : A case study. Sci. World J. 2: 10-17.

5. McCrady HM. 1915. The numerical interpretation of fermentation-tube results. J. Inf. Diseases. 17: 183-212.

6. Waite WM. 1985. A critical appraisal of the coliform test. JIWSDI. 39: 341357.

7. HMSO. (1996). Method for the isolation and identification of Escherichia coli $\mathrm{O} 157: \mathrm{H} 7$ from waters. Methods for the Examination of Water and Associated Materials. HMSO, London.

8. Watkins J, Xiangrong J. 1997. The Microbiological Quality of Water. Freshwater Biological Association, Ambleside, UK

9. MacConkey AT. 1908. Bile salt media and their advantages in some bacteriological examinations. J. Hyg. 8: 322-334.

10. Environmental Conservation Rules. 1997. Department of Environment, Government Republic of Bangladesh. 